\title{
SAG: A Schwann Cell Membrane Glycoprotein
}

\author{
Michael E. Dieperink, ${ }^{1}$ Alison O'Neill, ${ }^{1}$ Gladys Magnoni, ${ }^{1}$ Robert L. Wollmann,, Robert L. Heinrikson, ${ }^{2}$ Heidi A. \\ Zürcher-Neely, ${ }^{2}$ and Kari Stefansson ${ }^{1}$
}

'Departments of Neurology and Pathology (Neuropathology) and the Committees on Neurobiology and Immunology, The University of Chicago, Chicago, Illinois 60637 and ${ }^{2}$ The Upjohn Company, Kalamazoo, Michigan 49001

\begin{abstract}
We report on characterization of a 170,000 Da glycoprotein found exclusively in the PNS. We refer to this protein as the Schwann cell membrane glycoprotein (SAG). SAG contains the HNK-1 carbohydrate, which is considered by some to be a marker of adhesion molecules. Its $\mathrm{N}$-terminal sequence is not similar to previously known polypeptide sequences. SAG is found exclusively in the PNS, is present in rat sciatic nerve prior to myelination, and is in both myelinating and nonmyelinating Schwann cells. Tumors of Schwann cell lineage express SAG where axons are present (neurofibromas) but do not in the absence of axons (schwannomas). Schwannoma cells in culture do not express SAG even when exposed to forskolin, an activator of adenylate cyclase. However, schwannoma cells grown in the presence of a neuronal cell line (PC12) express SAG.
\end{abstract}

There are at least two types of glial cells in the PNS, satellite cells surrounding neuronal perikarya in ganglia, and Schwann cells surrounding axons (Tennyson and Gershon, 1984; Thomas and Ochoa, 1984). All axons are ensheathed by Schwann cells, but myelin is only made by Schwann cells under certain circumstances (Peterson and Murray, 1955; Peters and Vaughn, 1970; Voyvodic, 1989). It is likely that neurite outgrowth, Schwann cell ensheathment of axons, and myelination require complex interactions between axons and Schwann cells (Aguayo et al., 1976; Weinberg and Spencer, 1979; Politis et al., 1982). There appears to be an initial recognition between the two cell types that then leads Schwann cells either only to surround axons or also to myelinate them. The signal to myelinate is provided by axons of a certain diameter (Friede and Samorajski, 1968; Voyvodic, 1989) and may (Sobue et al., 1986) or may not (Mirsky et al., 1990) depend on activation of adenylate cyclase.

One approach to understanding the mechanism of Schwann cell-axon interactions is to study expression of molecules on the surfaces of Schwann cells and axons during development and regeneration of peripheral nerves (Trapp et al., 1981; Poduslo,

\footnotetext{
Received July 22, 1991; revised Jan. 2, 1992; accepted Jan. 8, 1992.

We thank Dr. Jonathan Art for expert assistance in the use of his confocal microscope. This work was supported in part by grants from the National Institutes of Health, the National Multiple Sclerosis Society, and the Lucille P. Markey Charitable Trust (K.S.). M.E.D. was supported by NIH Training Grant PHS 5T32 07195-09.

Correspondence should be addressed to Kari Stefansson, Department of Neurology/BH Box 425, The University of Chicago, 5841 South Maryland Avenue, Chicago, IL 60637 .

Copyright (C) 1992 Society for Neuroscience $0270-6474 / 92 / 122177-09 \$ 05.00 / 0$
}

1984). These molecules can be studied by observing conditions under which they are expressed in vivo and in vitro and correlating their expression with development and maturation of the axon-Schwann cell unit.

Nonmyelinating Schwann cells express glial fibrillary acidic protein, A5E3, Ran-2, 217c(Ran-1), NCAM, and L1/NgCAM (Yen and Fields, 1981; Jessen and Mirsky, 1984; Jessen et al., 1984, 1990; Mirsky et al., 1986), while myelin-forming cells do not. The myelin proteins P0, P1, P2, and myelin-associated glycoprotein are found exclusively in myelin-forming Schwann cells (Trapp et al., 1981; Brostofr, 1984; Sutcliffe, 1987). During development, both Schwann cells and axons express L1/NgCAM and NCAM when they first come in contact; however, these cell adhesion molecules are sharply downregulated during myelination (Martini and Schachner, 1986; Künemund et al., 1988), while myelin-associated glycoprotein first appears at this time (Martini and Schachner, 1986). Schwann cells and axons not involved in myelination continue to express L1 and NCAM into adulthood (Seilheimer and Schachner, 1987). Galactocerebroside (GC) (Jessen et al., 1985), sulfatide as recognized by antibody A007 (Mirsky et al., 1990), and the S100 protein (Stefansson et al., 1982a) are expressed by both myelinating and nonmyelinating Schwann cells.

Schwann cells have been cultured in the presence or absence of axons making it possible to deduce the effects of axons on expression of Schwann cell molecules (Kreider et al., 1981). Schwann cells continue to express Ran-1 (Brockes et al., 1977) and the S100 protein (Brockes et al., 1979) in the absence of continuous axonal contact, whereas the myelin proteins (Brockes et al., 1980, 1981; Mirsky et al., 1980), P170k (Shuman et al., 1988), GC (Mirsky et al., 1980), and sulfatide recognized by antibodies 04 and A007 (Jessen et al., 1990) are sharply downregulated. Activation of adenylate cyclase induces in cultured Schwann cells the expression of GC (Sobue and Pleasure, 1984; Sobue et al., 1986), sulfatide (Jessen et al., 1990), and the myelin proteins P0 and P1 (Lemke and Chao, 1988).

The investigation of these Schwann cell markers and the conditions under which they are or are not expressed has increased our understanding of the function of these molecules as well as our understanding of the complex system of axon-Schwann cell interactions. We have identified in peripheral nerve and begun to characterize a $170,000 \mathrm{Da}$ glycoprotein, which we call the Schwann cell membrane glycoprotein (SAG). SAG is probably, but not definitely, the same as a protein that has previously been described under the term P170k (Shuman et al., 1983). We postulate that SAG may be a cell adhesion molecule involved in interactions between Schwann cells and axons. 


\section{Materials and Methods}

Tissue samples. Human samples including cauda equina were obtained at autopsy performed less than $24 \mathrm{hr}$ after death. Bovine spinal roots were obtained from a local vendor less than $2 \mathrm{hr}$ after death and transported on ice. Lewis rats were obtained from Harlan Sprague Dawley. Fifteen neurofibromas and 15 schwannomas were retrieved from the archives of the Department of Pathology at the University of Chicago. The diagnoses were ascertained by two of the authors who are boardcertified neuropathologists (K.S. and R.L.W.) by determining that the tumors fulfill classic histologic criteria (Russel and Rubinstein, 1989) and the cells express the $\mathrm{S} 100$ protein (Stefansson et al., 1982b).

Purification. Sciatic nerves were harvested from Lewis rats and stored at $-70^{\circ} \mathrm{C}$ until needed. All steps in the enrichment procedure were performed at $4^{\circ} \mathrm{C}$ with the exception of gel filtration, which was performed at room temperature. Myelin isolation was performed according to the method of Norton and Poduslo (1973). The rat peripheral nerve (PN) myelin was Dounce homogenized in 1\%(v/v) NP-40 in buffer A ( $50 \mathrm{~mm}$ Tris, $150 \mathrm{~mm}$ sodium chloride, $1 \mathrm{~mm}$ EDTA, $0.5 \mathrm{~mm}$ phenylmethylsulfonyl fluoride, $\mathrm{pH} \mathrm{7.6)}$ and nutated for $1 \mathrm{hr}$. This mixture was centrifuged at $50,000 \times g$ for $30 \mathrm{~min}$, and the supernatant was discarded. The resulting pellet was nutated with 5\% NP-40 in buffer A for $1 \mathrm{hr}$ and again centrifuged at $50,000 \times \mathrm{g}$ for $30 \mathrm{~min}$. The pellet was washed twice with buffer $A$, centrifuged as above, incubated with $1 \%$ deoxycholate in buffer $\mathrm{A}$ for $1 \mathrm{hr}$, and centrifuged at $50,000 \times \mathrm{g}$ for 30 min. The supernatant was collected and loaded onto a gel filtration column (Superose 6) run with an FPLC machine (Pharmacia) using 1\% deoxycholate in buffer $\mathrm{A}$ as the running buffer. The first peak after the void volume was collected, and some of the deoxycholate was removed with Bio-Beads SM2, mesh 20-50 (Bio-Rad), using the method of Horigome and Sugano (1983). The resulting solution was then dialyzed against distilled water and lyophilized. For the purpose of amino acid sequencing, SAG was isolated from the $1 \%$ deoxycholate extract with two additional methods, first, by using preparative polyacrylamide gel electrophoresis (PAGE) and electroelution and, second, by using PAGEseparated proteins from the $1 \%$ deoxycholate extract blotted onto an Immobilon membrane (Millipore, Bedford, MA) and excising the SAG band.

Antibodies. Monoclonal antibodies (mAbs) to P2 protein and SAG were raised by repeatedly immunizing Lewis rats with bovine $P 2$ protein prepared by the method of Brostoff et al. (1975). SAG is a trace contaminant when P2 is isolated utilizing this method but appears to be very immunogenic to the rat. The fusion of rat splenocytes and SP2/0 AG14 mouse myeloma cell line was performed according to a modification of a technique developed by Kohler and Milstein (1976; Gomez et al., 1979). Six mAbs to SAG were raised, and their specificites were determined by testing them extensively on immunoblots containing polypeptides from homogenates of various tissues as well as on isolated proteins. Antibodies to $\$ 100$ (Molnar et al., 1984) and sulfatide (A007) (Mirsky et al., 1990) were previously developed in our laboratory. A hybridoma producing anti-HNK-1 antibody was obtained from the American Type Tissue Collection (ATTC; Rockville, MD). A rabbit polyclonal antiserum to GC was provided by Dr. J. A. Benjamins, Wayne State University (Dyer and Benjamins, 1990).

Immunohistochemistry and immunochemistry. Sections $(6 \mu \mathrm{m})$ from formalin-fixed paraffin-embedded blocks of human autopsy or surgical material were used for the peroxidase-antiperoxidase (PAP) method of immunolocalization (Sternberger, 1979, pp. 104-169). Rat PAP complexes were obtained from Sternberger-Meyer Immunocytochemicals Inc. (Jarretsville, MD). Coverslips of PC12 and RT4D4 cells were stained using indirect immunofluorescence (Sternberger, 1979, pp. 24-58). Photographs were taken using either a Bio-Rad MRC 500 confocal microscope or a Leitz Diaplan microscope for fluorescence and bright field using Nomarski optics.

$P A G E$, immunoblots, and lectin binding. Protein samples and molecular weight standards (Bio-Rad Laboratories, Richmond, CA) were solubilized in $5.7 \mathrm{M}$ urea, $1 \%(\mathrm{w} / \mathrm{v})$ SDS, and $1 \%(\mathrm{v} / \mathrm{v}) 2$-mercaptoethanol, with pyronin $Y$ used as a dye, and heated at $100^{\circ} \mathrm{C}$ for $3 \mathrm{~min}$. The polypeptides in the samples were separated on a $0.75 \mathrm{~mm}$ SDS-PAGE gel using $6 \%$ polyacrylamide and $0.2 \%$ cross-linking as described by Lugtenberg et al. (1975). Gels were either directly stained with silver nitrate (Merril et al., 1984) or the polypeptides were electrically transferred from the gels onto a nitrocellulose membrane (Towbin et al., 1979). Western blotting and lectin staining were performed as previously described (Mikol and Stefansson, 1988). The lectins (Vector Labora- tories, Burlingame, $C A$ ) were used in the following concentrations: Con A, $25 \mu \mathrm{g} / \mathrm{ml}$; wheat germ agglutinin, $50 \mu \mathrm{g} / \mathrm{ml}$; peanut agglutinin, 100 $\mu \mathrm{g} / \mathrm{ml}$; and Ulex europaeus agglutinin I, $100 \mu \mathrm{g} / \mathrm{ml}$.

Amino acid sequencing. The samples used for the amino acid sequencing included a preparation enriched for SAG using detergent solubilization and gel filtration chromatography as described above, SAG isolated using preparative electrophoresis, and SAG excised from an Immobilon membrane. Protein sequence analysis was performed with automated Fdman degradation in an Applied Biosystems Model 470A gas-phase sequencer fitted with an on-line HPLC analyzer (model 120A) for phenylthiohydantoins. Peaks from the latter were integrated by a Nelson Analytical 2700 series chromatography data system connected in parallel with the recorder to the output of the model 120A HPLC system. The National Biomedical Research Foundation database and the FASTP and GaP programs from the University of Wisconsin Genetics Computer Group (Devereux et al., 1984) were employed in searches for sequence similarity.

PC12 and schwannoma culture. Rat schwannoma cell line RT4D4 (kindly provided by Dr. G. Dawson, The University of Chicago, Chicago, IL) (Imada and Sueoka, 1978) was passaged every $4 \mathrm{~d}$ in Dulbecco's modified Eagle's medium (MEM) with $10 \%$ fetal calf serum (FCS) and penicillin/streptomycin. The rat pheochromocytoma cell line PC12 (kindly provided by Dr. B. Wainer, The University of Chicago, Chicago, IL) was passaged every $4 \mathrm{~d}$ in Dulbecco's MEM with $10 \%$ FCS. A C6 glioma cell line was obtained from ATTC and passaged every $4 \mathrm{~d}$ in Dulbecco's MEM with $10 \%$ FCS. The co-culture experiments were performed in Linbro 24-well culture plates (Flow Laboratories, Inc., VA) with poly-L-lysine-coated coverslips in each well. PC12 or C6 glioma cells were plated at $1 \times 10^{5}$ cells/well. After $3 \mathrm{~d}$ in culture, $1 \times 10^{5}$ RT4D4 cells were added to each well and the cells were cocultured for $4 \mathrm{~d}$ before antibody staining. The cell numbers and timing were optimized for maximum SAG staining. Conditioned medium was prepared from $\mathrm{PC} 12$ cells by taking the supernatant from PC12 cells cultured for $4 \mathrm{~d}$ at $1 \times 10^{5}$ cells per well. RT4D4 cells were cultured until the cells were confluent or for $3 \mathrm{~d}$ on poly-L-lysine-coated coverslips at $1 \times 10^{5}$ cells per well, the supernatant aspirated, and the PC12 supernatant added. The RT4D4 cells were stained $4 \mathrm{~d}$ later.

RT4D4 cells were cultured on coverslips in the presence or absence of $2 \times 10^{-4} \mathrm{M}$ forskolin for $4 \mathrm{~d}$ (cells observed to be confluent) prior to antibody staining.

\section{Results}

\section{Identification and distribution}

We raised $\mathrm{mAbs}$ to a polypeptide from $\mathrm{PN}$ with an apparent molecular weight of approximately 170,000 (Fig. 1). This 170 $\mathrm{kDa}$ polypeptide, referred to as $\mathrm{SAG}$, is detectable on immunoblots containing polypeptides from rat, bovine, rabbit, and human PN. SAG is, however, not found in tissue samples taken from human brain, spinal cord, thyroid, lung, kidney, or testes (data not shown). The six mAbs raised were of the IgM isotype, and all had the same specificity by immunoblots and immunohistochemistry.

Immunohistochemical staining with $\mathrm{mAbs}$ to SAG demonstrates reactivity only with PN tissue (Fig. 2). No staining is seen on tissue sections from brain, spinal cord, striated muscle, spleen, testes, lung, thyroid, skin, liver, heart, small intestine, or kidney except where PN is present within the tissue. The staining is in both myelinated and unmyelinated nerves, as can be seen when immunohistochemical staining for SAG and the $\mathrm{P} 2$ protcin arc compared in a cross section of a branch of the sciatic nerve (Fig. 2) or in a longitudinal section of the sympathetic trunk. The staining for the $\mathrm{P} 2$ protein is much more restricted than for $S A G$ and at the same time more intense, making it unlikely that restricted distribution of $\mathrm{P} 2$ is caused by less sensitivity of the method used for its detection. It is also clear from Figure $2 A$ that the satellite cells of sympathetic ganglia do not stain for $\mathrm{SAG}$, which is also the case with satellite cells of dorsal root ganglia and of the myenteric plexus (data not 
shown). SAG does not appear to be in compact myelin, but on some cross sections of myelinated fibers there appears to be staining of either the periaxonal myelin or the outermost aspect of the myelin or both (Fig. 3). However, this observation is based on light microscopy and should be considered only indicative of the subcellular distribution of SAG.

A Western blot containing electrophoresed polypeptides from developing rat peripheral nerves and stained with an $\mathrm{mAb}$ to SAG shows a barely detectable amount of SAG at embryonic day 21 (E21), a large increase in SAG concentration between E21 and postnatal day 0 (PND0), and then a gradual increase in SAG concentration up to PND15. There is a slight decrease in SAG concentration between PND15 and adulthood (Fig. 4). This experiment was done twice, and the results were the same both times. In the rat, myelination of PN begins at approximately PND2, with the most rapid rate of myelination being from PND10 through PND20 (Friede and Samorajski, 1968). Therefore, the period of greatest increase in SAG concentration in rat sciatic nerve occurs prior to myelination.

Plexiform neurofibromas are tumors of Schwann cells with axons running through them. Some tumor cells in neurofibromas stain for SAG in a distribution that follows axonal elements within the tumor (Fig. 5). As expected, most of the tumor cells stain for the S100 protein (Stefansson et al., 1982b) but P2 protein is detected only in the myelinated fibers at the outskirt of the tumors. Schwannomas are tumors of Schwann cells without axons in them, and in contrast to neurofibromas, none of their tumor cells contain SAG (Fig. 6).

\section{In vitro expression}

The rat schwannoma cell line RT4D4 does not express SAG when grown in Dulbecco's MEM with $10 \%$ FCS. Activation of adenylate cyclase with forskolin, which increases expression of many myelin components in Schwann cells (Sobue and Pleasure, 1984; Sobue et al., 1986; Lemke and Chao, 1988; Jessen et al., 1990), does not induce expression of SAG in confluent or subconfluent cultures of RT4D4. However, forskolin dramatically increases expression of an epitope recognized by an antibody raised in our laboratory called A007 that reacts with sulfatide (Fig. 7) (Mirsky et al., 1990).

When the RT4D4 cells are co-cultured with PC1 2 cells for 3 or more days, SAG appears in the RT4D4 cells (Figs. 8, 9). SAG does not appear in co-cultures of RT4D4 cells and C6 glioma cells (data not shown). Induction of SAG may require cell-to-cell contact because applying conditioned medium from PC12 cells onto the RT4D4 cells is not sufficient to induce expression (data not shown). Co-culture of RT4D4 and PC12 cells also leads to expression of GC on RT4D4 cells. Only RT4D4 cells in contact with PC1 2 cells express SAG and GC; however, it is not clear whether all RT4D4 cells in contact with a PC12 cell express SAG and GC. Furthermore, it is not clear whether contact with $\mathrm{PC} 12$ processes is necessary for induction of SAG expression or contact with $\mathrm{PC} 12$ cell bodies suffices.

\section{Purification}

SAG was extracted from rat sciatic nerve by making use of its relative insolubility. SAG is not soluble in $8 \mathrm{~m}$ urea, $1 \%$ Triton $\mathrm{X}-100,1 \mathrm{M} \mathrm{KCl}, 1 \%$ CHAPS, $5 \% \mathrm{NP}-40,6 \mathrm{M}$ guanidine $\mathrm{HCl}$, or $30 \%$ acetonitrile, while it is soluble in $1 \%$ deoxycholate and $1 \%$ SDS. The solubility profile closely resembles that of P0 protein (Roomi et al., 1978) for which a purification scheme

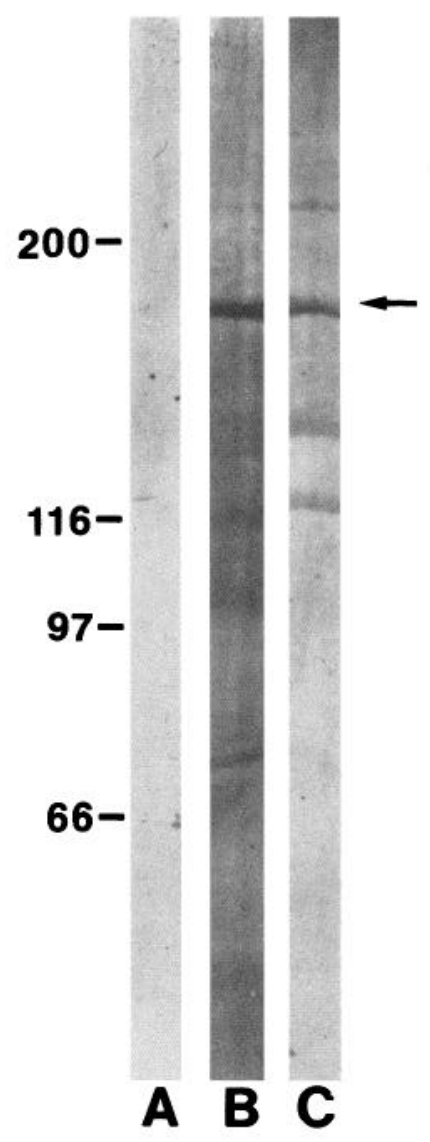

Figure 1. Western blot containing $50 \mu \mathrm{g}$ wet weight per lane of whole bovine PN (spinal roots) solubilized in SDS-urea buffer and separated by SDS-PAGE. Lane $A$ is a control and had the initial antibody step omitted. Lane $B$ was reacted with an $\mathrm{mAb}$ to $\mathrm{SAG}$, and lane $C$ was reacted with an $\mathrm{mAb}$ to the HNK-1 epitope. The strips were then followed with peroxidase-conjugated goat anti-rat antibodies. Molecular mass standards $(\mathrm{kDa})$ are shown: myosin, $200 ; \beta$-galactosidase, 116; phosphorylase $\mathrm{b}, 97$; BSA, 66 . The arrow points to a polypeptide at 170 $\mathrm{kDa}(\mathrm{SAG})$ that stains with both mAbs.

based on solubility was developed (Kitamura et al., 1976). We used a modification of this scheme and extracted PN myelin with $1 \%$ and $5 \%$ NP-40 each for $1 \mathrm{hr}$ and a $50,000 \times g$ pellet from the 5\% NP-40 extract was solubilized in $1 \%$ deoxycholate. A $50,000 \times g$ supernatant of the $1 \%$ deoxycholate extract was run over a gel filtration column (Superose 6), and the first peak following the void volume was collected and reacted with BioBeads SM-2 to remove the deoxycholate partially. The resulting solution was then dialyzed against distilled water and lyophilized. Analysis on a silver-stained SDS-PAGE gel showed only one major band (Fig. 10), but as demonstrated with N-terminal sequencing, this preparation was contaminated with the P0 protein. However, using this preparation as an immunogen, we were able to raise polyclonal antibodies that are specific for SAG and do not react with the $\mathrm{P} 0$ protein.

\section{Carbohydrate}

Lectin staining of Western blots of isolated rat SAG demonstrated binding to Ulex europaeus agglutinin I, peanut agglutinin, and WGA, but not Con A (data not shown). Bovine SAG purified from cauda equina contains the HNK-1 carbohydrate (Fig. 1), whereas rat SAG does not. Based on lectin staining, 

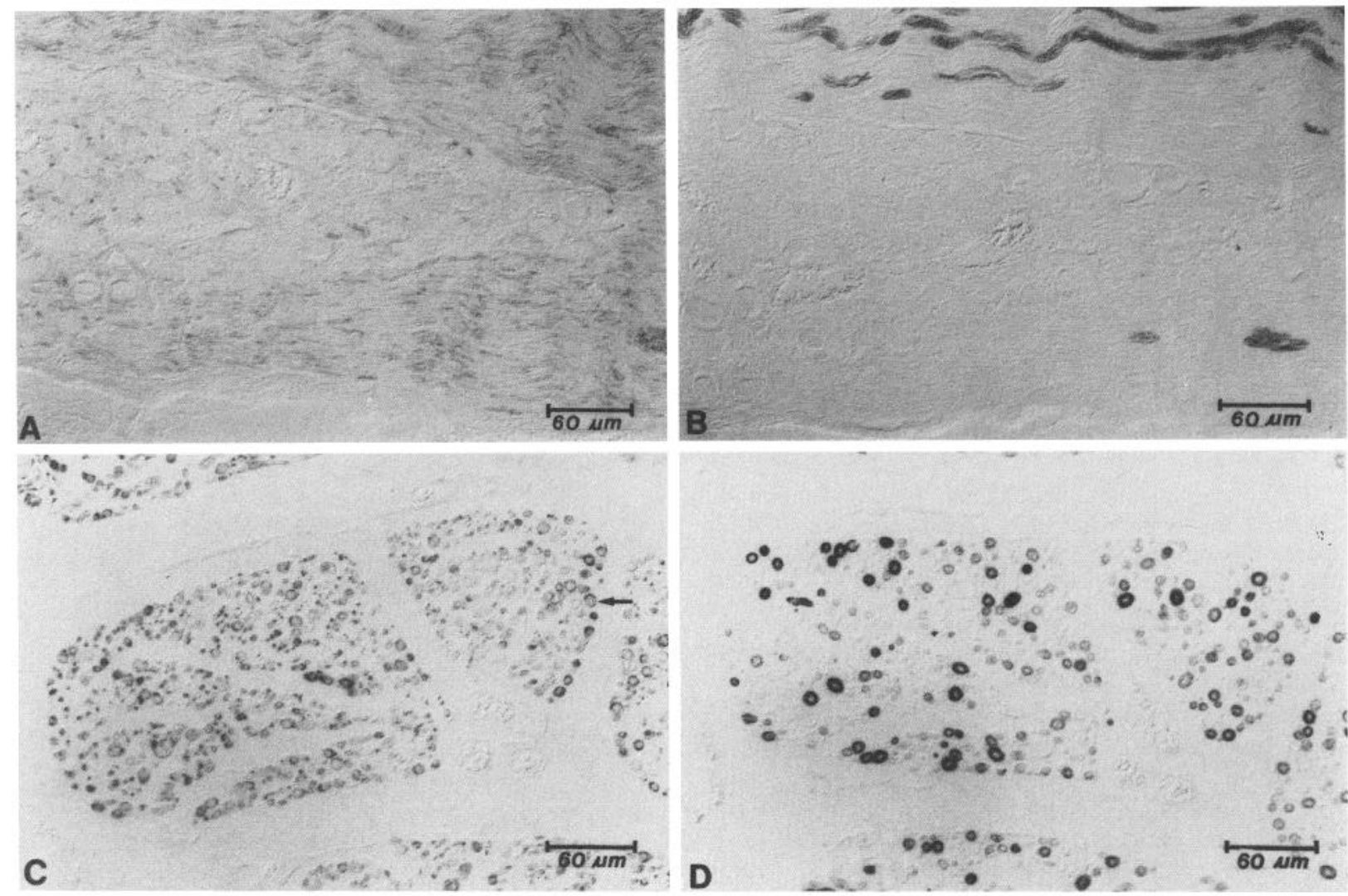

Figure 2. Localization of SAG using mAbs. PAP staining of formalin-fixed paraffin-embedded sections of human sympathetic trunk $(A$ and $B$ ) and human spinal root $(C$ and $D) . A$ and $C$ were stained with an mAb to SAG, while $B$ and $D$ were stained with an mAb to the P2 protein. The P2 protein is present in the compact myelin, in contrast to SAG, which in myelin appears to be confined to the outermost and periaxonal parts of the myelin $(C$, arrow $)$ and is also in the unmyelinated parts of the sympathetic trunk $(A)$. See Figure 3 for higher-power view.

tissue distribution, and size, SAG is likely to be the same as, or closely related to, a $170 \mathrm{kDa}$ glycoprotein described by Shuman et al. (1983) and called P170k.

\section{$\mathrm{NH}_{2}$-terminal amino acid sequence}

Three different preparations of SAG were subjected to automated Edman degradation. The first sample was partially pu-
A

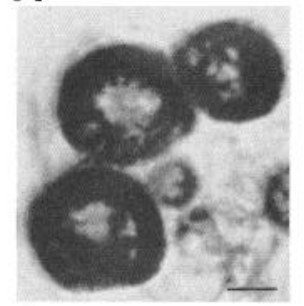

C

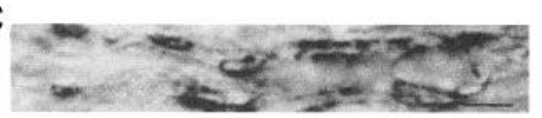

B

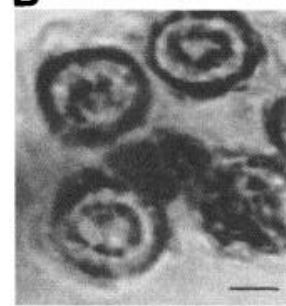

ser rified, then run with SDS-PAGE, followed by transfer to an Immobilon membrane. The membrane was stained with Coomassie blue, and the band at $170 \mathrm{kDa}$ was excised. Sequence analysis of this material gave one sequence in low yield. The second preparation sequenced was SAG enriched using the method described above. This sample contained more material of lesser purity than the first sample sequenced, and was composed of a predominant protein $(75 \%)$, the sequence of which corresponded to the $\mathrm{P} 0$ protein. The minor protein component $(25 \%)$ gave a sequence that agreed with, and extended that obtained from analysis of, SAG blotted onto the Immobilon membrane. The preparation enriched for SAG was heavily contaminated with myelin $\mathrm{P} 0$ protein despite having only a single band corresponding to $170 \mathrm{kDa}$ on a silver-stained SDS-PAGE gel (Fig. 10). A third sample was prepared by electroeluting a band

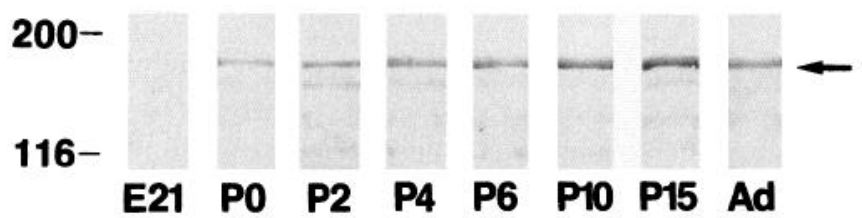

Figure 3. High-power view of SAG localization. PAP staining of human sciatic nerve in cross $(A$ and $B)$ and longitudinal $(C)$ sections. $A$ is stained with an $\mathrm{mAb}$ to the $\mathrm{P} 2$ protein, and $B$ and $C$ are stained with an $\mathrm{mAb}$ to SAG. This further supports the notion that SAG may be present only in the inner- and outermost aspects of myelin and not in the compact myelin. Scale bars, $5 \mu \mathrm{m}$.
Figure 4. Western blot of a $6 \%$ Laemmli SDS-PAGE gel containing proteins of sciatic nerve from rats of different ages starting at E21 and continuing through postnatal days $(P) 0, \mathrm{P} 2, \mathrm{P} 4, \mathrm{P} 6, \mathrm{P} 10, \mathrm{P} 15$, and adult $(A d)$. An equal amount of whole nerve $(60 \mu \mathrm{g}$ of wet weight) was applied to each lane. The blot was stained with an mAb to SAG. Numbers indicate molecular mass standards. 

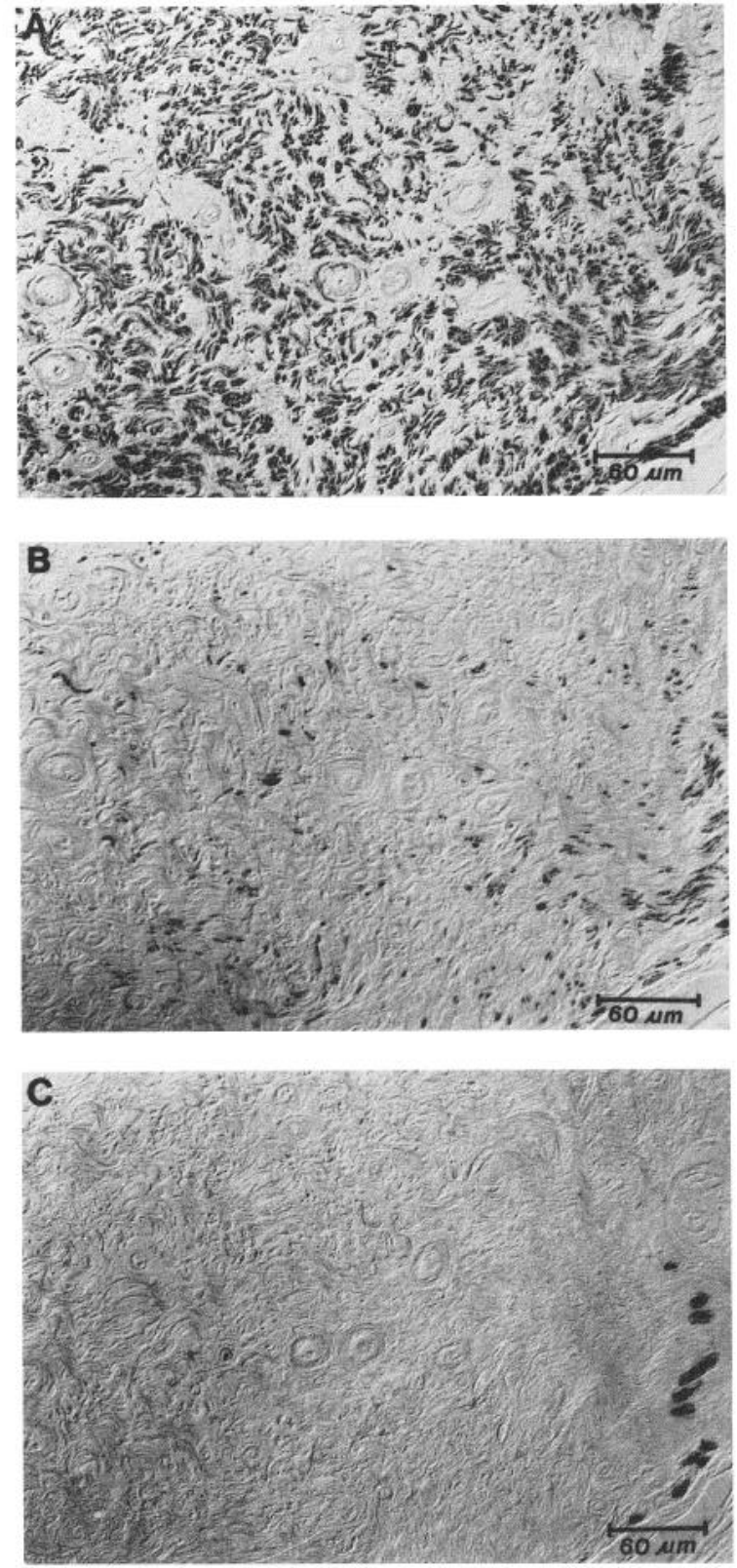

Figure 5. PAP staining of formalin-fixed paraffin-embedded sections of a human neurofibroma. $A$ is stained with an $\mathrm{mAb}$ to the $\mathrm{S} 100$ protein, $B$ with an $\mathrm{mAb}$ to $\mathrm{SAG}$, and $C$ with an $\mathrm{mAb}$ to the $\mathrm{P} 2$ protein. Most tumor cells stain for the S100 protein, but only a few stain for SAG. The staining pattern with the anti-SAG mAb is consistent with silver staining for axons in the same tumor. Myelin, as indicated by staining with the mAb to the $\mathrm{P} 2$ protein, is only present at the periphery of the tumor.

corresponding to SAG from PAGE. This sample was without contamination and yielded a sequence that was identical to the other two. The sequence, shown in Figure 11, did not match any protein in the databases searched, nor was there close similarity to a previously described protein.

\section{Discussion}

In this article we describe a PN glycoprotein we call SAG, which may be the same as, or closely related to, a previously described protein called P170k (Shuman et al., 1986, 1988).
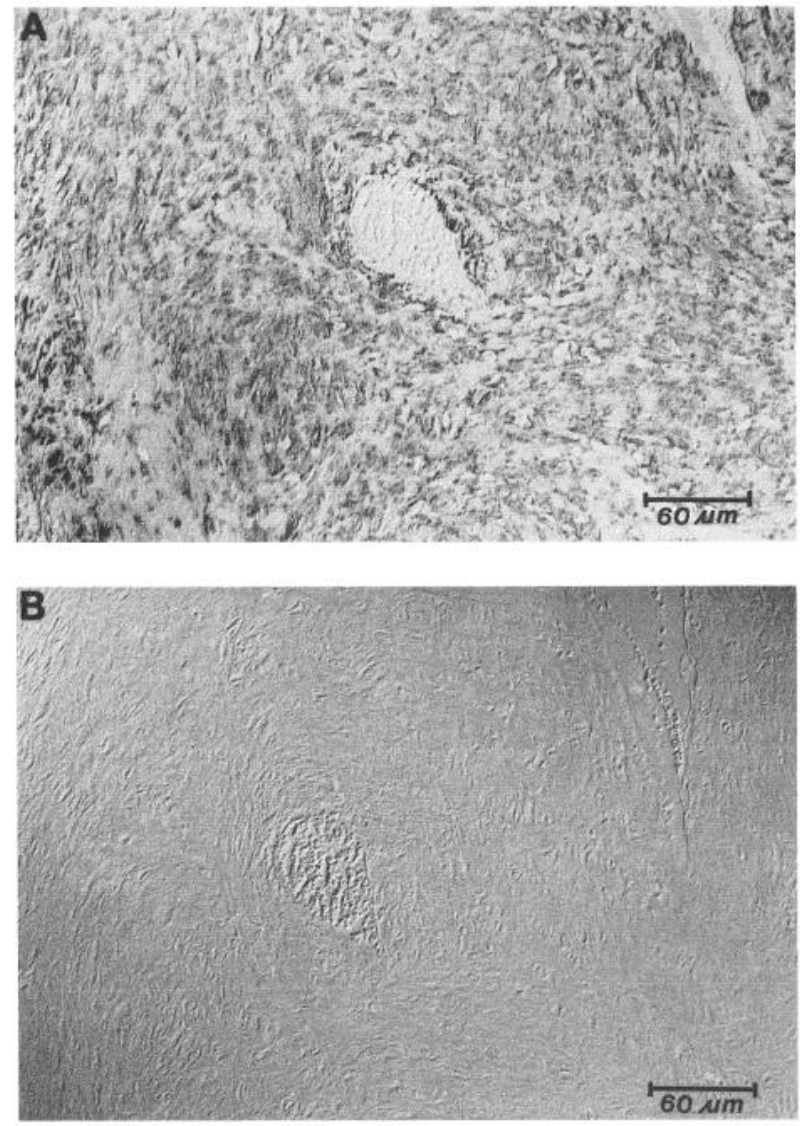

Figure 6. PAP staining of formalin-fixed paraffin-embedded sections of a human schwannoma. $A$ is stained with an $\mathrm{mAb}$ against $\mathrm{S} 100 ; B$ is stained with a mAb to SAG. The schwannoma, which contains no axons, does not express SAG, but the tumor cells, as expected, contain the S100 protein.

SAG has proven to be a difficult protein to work with because it has a tendency to degrade during attempts at isolation, despite application of protease inhibitors. Bovine and human SAG seem to be more susceptible to degradation than rat SAG. However, rat SAG yields degradation products that show up as minor bands on immunoblots. We were able to enrich for SAG to the extent that we could obtain its $\mathrm{N}$-terminal sequence, which is distinct from known polypeptide sequences. The $\mathrm{N}$-terminal sequence of SAG has a predominance of hydrophobic amino acids and does not display the pattern of charged and hydrophobic residues characteristic of signal sequences (von Heijne, 1984). This region could form a transmembrane $\alpha$-helical structure anchoring SAG to the cell membrane.

Our results demonstrate that SAG is confined to the PNS, is in PN prior to myelination, and is present in both myelinating and nonmyelinating Schwann cells. SAG does not appear to be present in compact myelin, but these data are based on light microscopy and definitive immunoelectron microscopy has not been performed. Hence, although some SAG is present in preparations of peripheral myelin, it is not confined to myelin, and it is probably more accurate to view it as a Schwann cell protein rather than a true myelin protein such as P0, P1, or P2. However, this does not preclude the possibility that SAG may play a role in myelination or contribute to the stability of the myelin sheath. SAG is not present in satellite cells of peripheral ganglia, which are in contact with neuronal perikarya rather than axons. SAG 

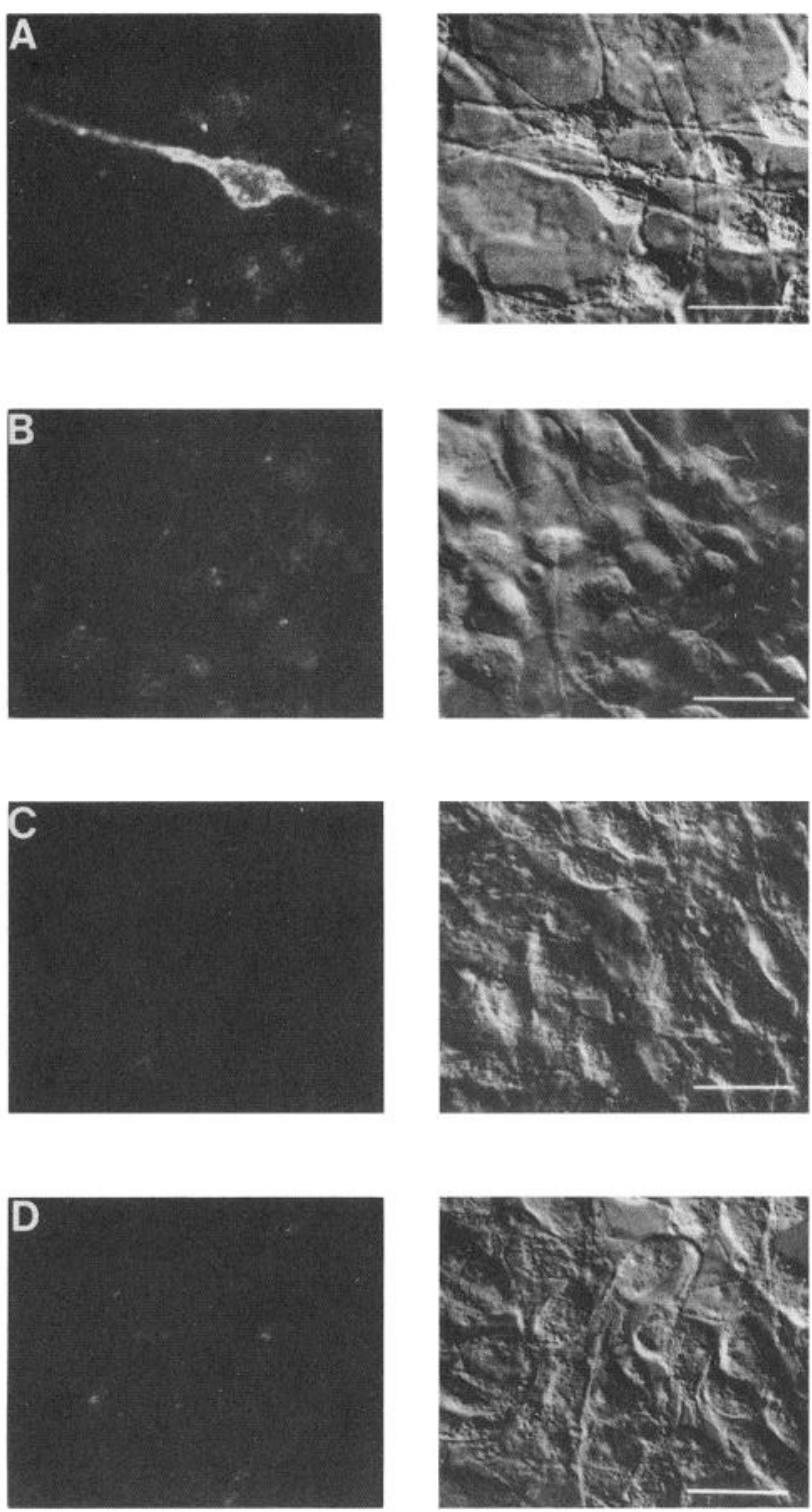

Figure 7. Culture of a rat schwannoma cell line, RT4D4, stained using fluorescein isothiocyanate (FITC) indirect immunofluorescence and visualized with a confocal microscope. Culture $A$ was grown in the presence of forskolin and stained with an $\mathrm{mAb}$ to sulfatide (A007). Culture $B$ was grown without forskolin and stained with $\mathrm{mAb} A 007$. Culture $C$ was grown in the presence of forskolin and stained with an $\mathrm{mAb}$ to SAG. Culture $D$ was grown without forskolin and stained with an $\mathrm{mAb}$ to SAG. In each case the corresponding bright-field micrograph using Nomarski optics is to the right. Forskolin does not induce expression of SAG in RT4D4 cells; however, expression of sulfatide is induced by forskolin in these cells. Scale bars, $25 \mu \mathrm{m}$.

is expressed by neurofibromas, which contain axonal elements, but not by schwannomas, which are Schwann cell tumors devoid of axons; this suggests that presence of axons may be necessary for cells of Schwann cell lineage to express SAG.

Further support for the possibility that neuronal contact is necessary for the expression of SAG comes from the co-culture experiments. Schwannoma cells alone in culture or when cocultured with $\mathrm{C} 6$ glioma cells do not express SAG, whereas the schwannoma cells co-cultured with PC12 cells do. Since supernatants from PC12 cultures do not induce expression of SAG, the induction may require membrane contact. However, the
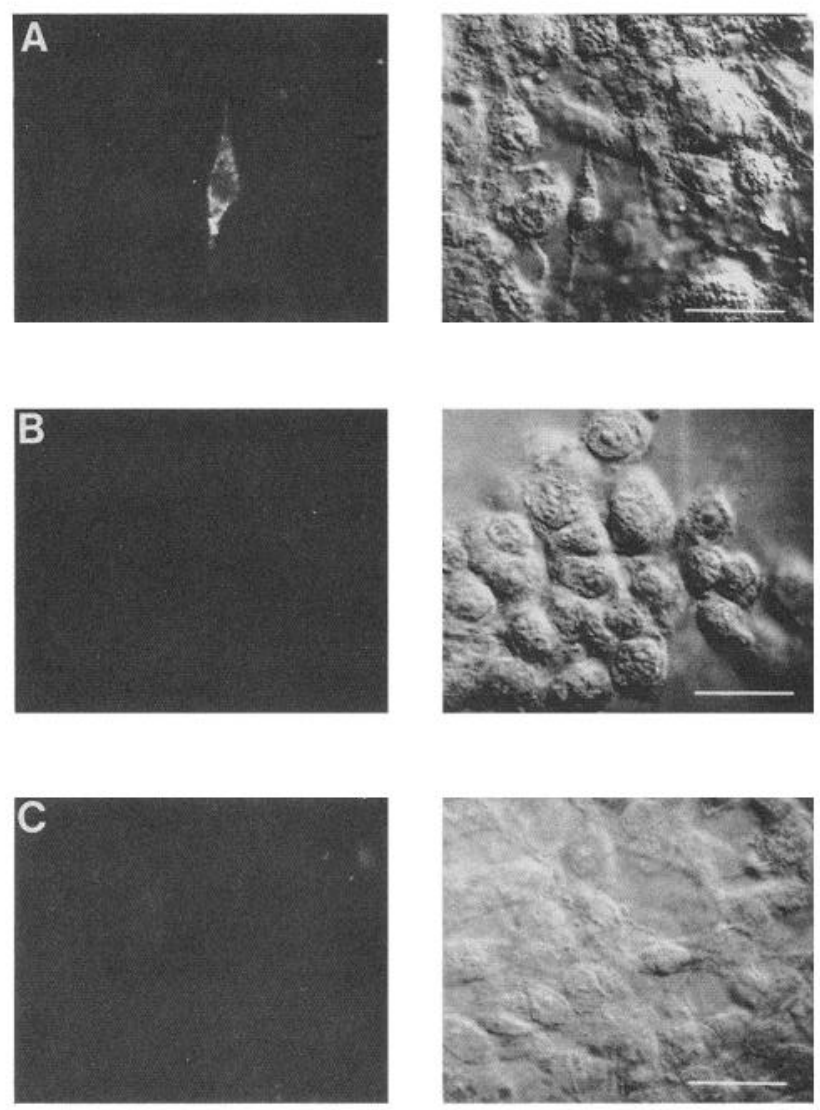

Figure 8. Cells stained using FITC indirect immunofluorescence with an $\mathrm{mAb}$ to SAG and visualized using a confocal microscope. $A$ is a coculture of RT4D4 cells with PC12 cells, $B$ is a culture of PC12 cells, and $C$ is a culture of RT4D4 cells. The corresponding bright-field micrographs using Nomarski optics appear to the right of the fluorescent figures. Only cells in the co-culture express SAG. Scale bars, $25 \mu \mathrm{m}$.

experiments described here do not establish that the ability to induce SAG expression in vitro is a property specific to cell lines of neuronal lineage, although the $\mathrm{PC} 12$ cells induce expression of SAG on the schwannoma cells and the C6 glioma cells do not.

Forskolin does not induce expression of SAG in schwannoma cells, indicating that the signal from the $\mathrm{PC1} 2$ cells to the schwannoma cells is not received by a cAMP-dependent mechanism. This is in contrast to the myelin proteins P0 and P1,
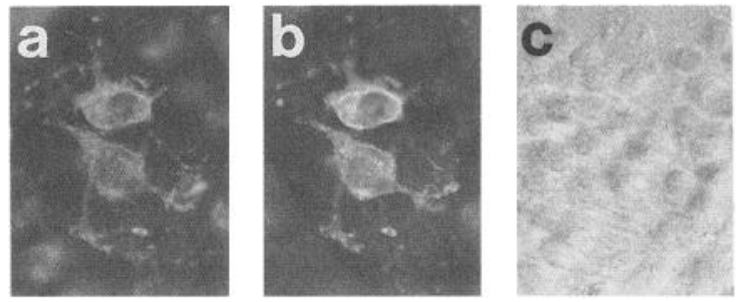

Figure 9. Co-culture of RT4D4 cells with PC12 cells stained using immunofluorescence. The culture was stained with a rabbit polyclonal antibody to $\mathrm{GC}$ followed by tetramethylrhodamine isothiocyanate-conjugated swine anti-rabbit $(A)$ and an mAb to SAG followed by FITCconjugated rabbit anti-rat $(B)$. A bright-field micrograph using Nomarski optics of the same field is shown in $C$. All cells expressing SAG in the co-culture also express GC and are therefore considered schwannoma cells. 


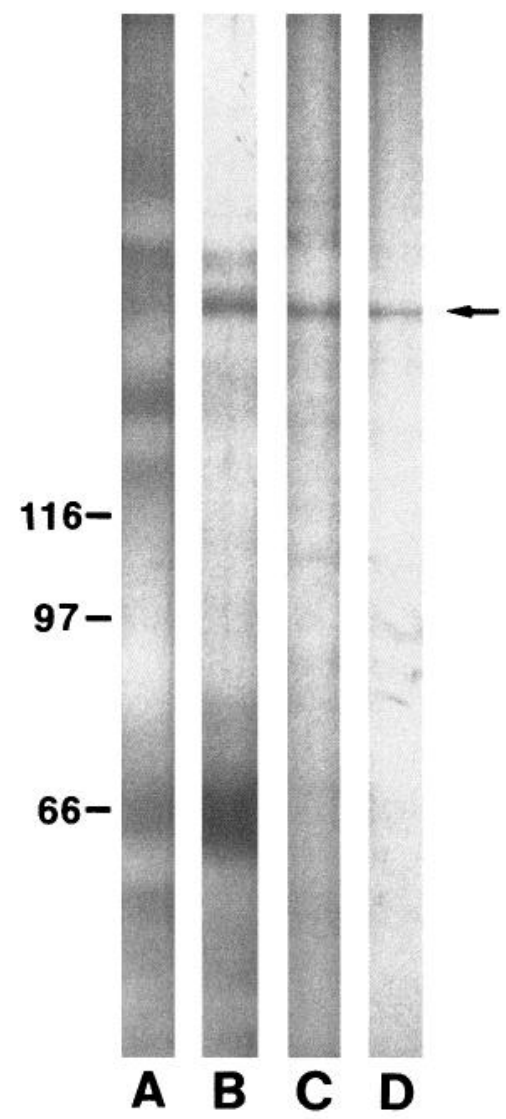

Figure 10. Enrichment of SAG: silver stain of an SDS-PAGE gel containing the steps in the SAG enrichment scheme from rat PN. Lane A contains protein from unfractionated rat sciatic nerve. Myelin was isolated from rat PN (lane B), which was extracted with NP-40 and pelleted. This pellet (lane $C$ ) was extracted with $1 \%$ deoxycholate, and the supernatant (lane D) was shown to be homogeneous SAG by silver stain. However, $\mathrm{N}$-terminal sequencing showed it to be contaminated with $\mathrm{P} 0$ protein.

which are induced in cultured Schwann cells by forskolin (Lemke and Chao, 1988). In addition, these results differ from those of Shuman et al. (1988), who found P170k to be forskolin inducible in cultured rat Schwann cells. However, it is important to emphasize that the experiments described here were done with a schwannoma cell line whereas Shuman et al. (1988) worked with primary cultures of Schwann cells. The PC12 cell line is also a tumor cell line, and it could be argued that using a neuronal tumor cell line to induce expression of a protein on the surface of a schwannoma cell line constitutes a nonphysiologic system. However, rat schwannoma cell lines have been shown to support neurite outgrowth (Tomaselli and Reichardt, 1988) and the PC12 cell line has been used productively to study neuronal properties; for example, it was used in studies of molecules that are important for neurite extension (Tomaselli et al., 1987, 1988, 1990).

Interactions between PC12 and Schwann cells have previously been studied, and it has been determined that Schwann cells are not able to ensheath PC12 neurites, assemble basal lamina, or differentiate when co-cultured with PC12 cells (Cochran, 1985). However, there are interactions between Schwann cells and PC12 cells that lead to changes in morphology and mitotic rate of the cells (Cochran and Black, 1985), although they do not lead to ensheathment or myelination. Therefore, it is likely that the molecules involved in this interaction are also involved in early interactions between Schwann cells and axons. Schwannoma cells do express SAG when co-cultured with PC12 cells, and SAG may therefore be such a molecule. This conclusion is, in part, based on the assumption that Schwann cell ensheathment of the axon, which is a process distinct from myelination, is also distinct from the early interactions between the Schwann cell and the axon.

When viewed together, the results of the study on the tissue distribution of SAG and the results of the co-culture experiments constitute compelling circumstantial evidence in support of the possibility that expression of SAG on Schwann cells is induced by contact between Schwann cells and neurons. Furthermore, the presence of SAG on Schwann cells and absence from satellite cells of ganglia indicate that contact with axons may be required for SAG expression and contact with perikarya is not sufficient.

SAG carries the HNK-1 carbohydrate, which is characteristic of many adhesion molecules (McGarry et al., 1983; Kruse et al., 1984, 1985) and may in itself be capable of mediating adhesion (Künemund et al., 1988). Therefore, it is tempting to postulate that SAG may be responsible for some aspects of Schwann cell-axon adherence. However, since SAG is not expressed in a constitutive fashion on Schwann cells, it is probably not responsible for the original binding of Schwann cells to axons. In addition, since SAG is expressed not only in the adaxonal part of the myelin sheath but also in the abaxonal part (not in compact myelin), it is possible that the role of SAG is not limited to Schwann cell-axon interactions.

The expression of SAG may be regulated in a distinct manner. In Schwann cell cultures, myelin proteins are downregulated in the absence of continuous axonal stimulation (Brockes et al., 1979, 1981). Ran-1 (Brockes et al., 1977) and S100 protein (Brockes et al., 1979) are constitutively expressed by Schwann cells, and NCAM and L1/NgCAM (Nieke and Schachner, 1985; Daniloff et al., 1986) are upregulated in the absence of axons. SAG is the only protein we know of, not confined to myelin, that is probably dependent on continuous axonal signals. The regulation of SAG is most reminiscent of GC and sulfatide, both of which are present in myelinating and nonmyelinating Schwann cells and require axonal input for continued expression (Jessen et al., 1985, 1987). However, the regulation of these glycolipids is thought to be through cAMP-dependent mechanisms (Sobue et al., 1986; Mirsky et al., 1990). The expression of SAG appears to be regulated in a different manner and may therefore have a unique function in Schwann cell-axon interactions.

\section{References}

Aguayo AJ, Epps J, Charron L, Bray GM (1976) Multipotentiality of Schwann cells in cross-anastomosed and grafted myelinated and un-

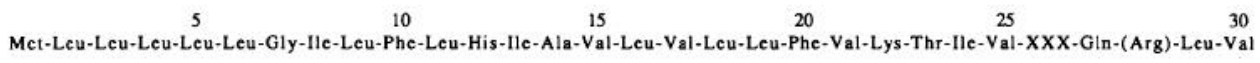

Figure 11. The amino-terminal sequence of SAG as deduced by automated Edman degradation of a sample on Immobilon membrane, a sample obtained from preparative electrophoresis, and a mixture of SAG and myelin P0 protein. A position not identified is indicated by $X X X$; the position in parentheses is a tentative assignment. 
myelinated nerves: quantitative microscopy and radioautography. Brain Res 104:1-20.

Brockes JP, Fields KL, Raff MC (1977) A surface antigenic marker for rat Schwann cells. Nature 266:364-366.

Brockes JP, Fields KL, Raff MC (1979) Studies on cultured rat Schwann cells. I. Establishment of purified population from cultures of peripheral nerve. Brain Res 165:105-118.

Brockes JP, Raff MC, Nishiguchi DJ, Winter J (1980) Studies on cultured rat Schwann cells. III. Assays for peripheral myelin proteins. J Neurocytol 9:66-77.

Brockes JP, Fryxell KJ, Lemke GE (1981) Studies on cultured Schwann cclls: the induction of myelin synthesis and the control of their proliferation by a new growth factor. J Exp Biol 95:215-230.

Brostoff SW (1984) Antigens of peripheral nervous system myelin. In: Peripheral neuropathy (Dyck PJ, Thomas PK, Lambert EH, Bunge RP, eds), pp 562-576. Philadelphia: Saunders.

Brostoff SW, Sacks H, Di Paola C (1975) The P2 protein of bovine root myelin: partial chemical characterization. J Neurochem 24:289294.

Cochran M (1985) Schwann cells fail to differentiate when co-cultured in contact with PC12 neurites. Dev Brain Res 19:89-100.

Cochran M, Black MM (1985) PC12 neurite regeneration and longterm maintenance in the absence of exogenous nerve growth factor in response to contact with Schwann cells. Dev Brain Res 17:105116.

Daniloff JK, Levi G, Grumet M, Ricger F, Edelman GM (1986) Altered expression of neuronal cell adhesion molecules induced by nerve injury and repair. J Cell Biol 103:929-945.

Devereux J, Haeberli P, Smithies O (1984) A comprehensive set of sequence analysis programs for the VAX. Nucleic Acids Res 12:387395.

Dyer CA, Benjamins JA (1990) Glycolipids and transmembrane signaling: antibodies to galactocerebroside cause an influx of calcium in oligodendrocytes. J Cell Biol 111:625-633.

Friede RL, Samorajski T (1968) Myelin formation in the sciatic nerve of the rat. A quantitative electron microscopic, histochemical and radiographic study. J Neuropath Exp Neurol 27:546-570.

Gomez CM, Richman DP, Berman PW, Burres SA, Arnason BGW, Fitch FW (1979) Monoclonal antibodies against purified nicotinic acetylcholine receptor. Biochem Biophys Res Commun 88:575-582.

Horigome T, Sugano H (1983) A rapid method for removal of detergents from protein solution. Anal Biochem 130:393-396.

Imada M, Sueoka N (1978) Clonal sublines of rat RT4 and cell differentiation. I. Isolation and characterization of cell lines and cell type conversion. Dev Biol 66:97-108.

Jessen KR, Mirsky R (1984) Non myelin-forming Schwann cells coexpress surface proteins and intermediate filaments not found in myelinforming cells: a study of Ran-2, A5E3 antigen and glial fibrillary acidic protein. J Neurocytol 13:923-934.

Jessen KR, Thorpe R, Mirsky R (1984) Molecular identity, distribution and heterogeneity of glial fibrillary acidic protein: an immunoblotting and immunohistochemical study of Schwann cells, satellite cells, enteric glia and astrocytes. J Neurocytol 13:187-200.

Jessen KR, Morgan L, Brammer M, Mirsky R (1985) Galactocerebroside is expressed by non-myelin-forming Schwann cells in situ. J Cell Biol 101:1135-1143.

Jessen KR, Morgan L, Mirsky R (1987) Axonal signals regulate the differentiation of non-myelin-forming Schwann cells: an immunohistochemical study of galactocerebroside in transected and regenerating nerves. J Neurosci 7:3362-3369.

Jessen KR, Morgan L, Stewart HJS, Mirsky R (1990) Three markers of adult non-myelin-forming Schwann cells, 217c(Ran-1), A5E3 and GFAP: development and regulation by neuron-Schwann cell interactions. Development 109:91-103.

Kitamura K, Suzuki M, Uyemura K (1976) Purification and partial characterization of two glycoproteins in bovine peripheral nerve myelin membrane. Biochim Biophys Acta 455:806-816.

Kohler G, Milstein C (1976) Derivation of specific antibody-producing tissue culture and tumor lines by cell fusion. Eur J Immunol 5:511519.

Kreider BQ, Messing A, Doan H, Kim SV, Lisak RP, Pleasure DE (1981) Enrichment of Schwann cell cultures from neonatal rat sciatic nerve by differential adhesion. Brain Res 207:433-444.

Kruse J, Mailhammer R, Wernecke H, Faissner A, Sommer I, Goridis C, Schachner M (1984) Neural cell adhesion molecules and myelin- associated glycoprotein share a common carbohydrate moiety recognized by monoclonal antibodies L2 and HNK-1. Nature 311:153155.

Kruse J, Keilhauer G, Faissner A, Timpl R, Schachner M (1985) The Jl glycoprotein: a novel nervous system cell adhesion molecule of the L2/HNK-1 family. Nature 316:146-148.

Künemund V, Jungalwala FB, Fischer G, Chou DKH, Keilhauer G, Schachner M (1988) The L2/HNK-1 carbohydrate of neural cell adhesion molecules is involved in cell interactions. J Cell Biol 106 213-223.

Lemke G, Chao M (1988) Axons regulate Schwann cell expression of the major myelin and NGF receptor genes. Development 102:499504.

Lugtenberg B, Meijers J, Peters R, van der Hoek P, van Alphen L (1975) Electrophoretic resolution of the 'major outer membrane protein' of Escherichia coli $\mathrm{K} 12$ into four bands. FEBS Lett 58:254-258.

Martini R, Schachner M (1986) Immunoelectron microscopic localization of neural cell adhesion molecules (L1, N-CAM, MAG) and their carbohydrate epitope and myelin basic protein (MBP) in developing sciatic nerve. J Cell Biol 103:2439-2448.

McGarry RC, Helfand SL, Quarles RH, Roder JC (1983) Recognition of myelin-associated glycoprotein by the monoclonal antibody HNK1. Nature 306:376-378.

Merril CR, Goldman D, Van Keuren ML (1984) Gel protein stains: silver stain. Methods Enzymol 104:441-447.

Mikol DD, Stefansson K (1988) A phosphatidylinositol-linked peanut agglutinin-binding glycoprotein in central nervous system myelin and on oligodendrocytes. J Cell Biol 106:1273-1279.

Mirsky R, Winter J, Abney ER, Pruss RM, Gavrilovic J, Raff MC (1980) Myelin-specific proteins and glycolipids in rat Schwann cells and oligodendrocytes in culture. J Cell Biol 84:483-494.

Mirsky R, Jessen KR, Schachner M, Goridis C (1986) Distribution of the adhesion molecules N-CAM and $\mathrm{L} 1$ on peripheral neurons and glia in adult rats. $\mathrm{J}$ Neurocytol 15:799-815.

Mirsky R, DuBois C, Morgan L, Jessen KR (1990) O4 and A007sulfatide antibodies bind to embryonic Schwann cells prior to the appearance of galactocerebroside; regulation of the antigen by axonSchwann cell signals and cyclic AMP. Development 109:105-116.

Molnar ML, Stefansson K, Marton LS, Tripathi RC, Molnar GK (1984) Distribution of S-100 protein and glial fibrillary acidic protein in normal and gliotic human retina. Exp Eye Res 38:27-34.

Nieke J, Schachner M (1985) Expression of the neural cell adhesion molecules L1 and N-CAM and their common carbohydrate epitope L2-HNK-1 during development and after transection of adult mouse sciatic nerve. Differentiation 30:141-151.

Norton WT, Poduslo SE (1973) Myelination in rat brain: method of myelin isolation. J Neurochem 21:749-757.

Peters A, Vaughn JE (1970) Morphology and development of the myelin sheath. In: Myelination (Davidson AN, Peters A, eds), pp 379. Springfield, IL: Thomas.

Peterson ER, Murray MR (1955) Myelin sheath formation in cultures of avian spinal ganglia. Am J Anat 96:319-355.

Poduslo JF (1984) Regulation of myelination: biosynthesis of the major myelin glycoprotein by Schwann cells in the presence and absence of myelin assembly. J Neurochem 42:493-503.

Politis MJ, Sternberger N, Ederle K, Spencer PS (1982) Studies on the control of myelinogenesis. IV. Neuronal induction of Schwann cell myelin-specific protein synthesis during nerve fiber regeneration. J Neurosci 2:1252-1266.

Roomi MW, Ishaque A, Khan NR, Eylar EH (1978) The P0 protein: the major glycoprotein of peripheral nerve myelin. Biochim Biophys Acta 536:112-121.

Russel DS, Rubinstein LJ (1989) Pathology of tumors of the nervous system. Baltimore: Williams and Wilkins.

Seilheimer B, Schachner M (1987) Regulation of neural cell adhesion molecule expression of cultured mouse Schwann cells by nerve growth factor. EMBO J 6:1611-1616.

Shuman S, Hardy M, Pleasure DE (1983) Peripheral nervous system myelin and Schwann cell glycoproteins: identification by lectin binding and partial purification of a peripheral nervous system myelinspecific 170,000 molecular weight glycoprotein. J Neurochem 41 : $1277-1285$.

Shuman S, Hardy M, Pleasure DE (1986) Immunochemical characterization of peripheral nervous system myelin $170,000-M$, glycoprotein. J Neurochem 47:811-818. 
Shuman S, Hardy M, Sobue G, Pleasure DE (1988) A cyclic AMP analogue induces synthesis of a myelin-specific glycoprotein by cultured Schwann cells. J Neurochem 50:190-194.

Sobue G, Pleasure DE (1984) Schwann cell galactocerebroside induced by derivatives of adenosine $3^{\prime}, 5^{\prime}$-monophosphate. Science $224: 72-$ 74 .

Sobue G, Shuman S, Pleasure DE (1986) Schwann cell responses to cyclic AMP: proliferation, change in shape, and appearance of surface galactocerebroside. Brain Res 362:23-32.

Stefansson K, Wollmann RL, Moore BW (1982a) Distribution of S-100 protein outside the central nervous system. Brain Res 234:309-317.

Stefansson K, Wollmann RL, Jerkovic M (1982b) S-100 protein in soft-tissue tumors derived from Schwann cells and melanocytes. Am J Pathol 106:261-268.

Sternberger LA (1979) Immunocytochemistry. New York: Wiley.

Sutcliffe JG (1987) The genes for myelin. Trends Genet 3:73-76.

Tennyson VM, Gershon MD (1984) Light and electron microscopy of dorsal root, sympathetic, and enteric ganglia. In: Peripheral neuropathy (Dyck PJ, Thomas PK, Lambert EH, Bunge RP, eds), pp 121-155. Philadelphia: Saunders.

Thomas PK, Ochoa J (1984) Microscopic anatomy of peripheral nerve fibers. In: Peripheral neuropathy (Dyck PJ, Thomas PK, Lambert EH, Bunge RP, eds), pp 39-96. Philadelphia: Saunders.

Tomaselli KJ, Reichardt LF (1988) Peripheral motorneuron interactions with laminin and Schwann cell-derived neurite-promoting molecules: developmental regulation of laminin receptor function. J Neurosci Res 21:275-285.

Tomaselli KJ, Damsky CH, Reichardt LF (1987) Interactions of a neuronal cell line (PC12) with laminin, collagen IV, and fibronectin: identification of integrin-related glycoproteins involved in attachment and process outgrowth. J Cell Biol 105:2347-2358.
Tomaselli KJ, Damsky CH, Reichardt LF (1988) Purification and characterization of mammalian integrins expressed by a rat neuronal cell line (PC12): evidencc that thcy function as alpha/beta heterodimeric receptors for laminin and type IV collagen. J Cell Biol 107: 1241-1252.

Tomaselli KJ, Hall DE, Flier LA, Gehlsen KR, Turner DC, Carbonetto S, Reichardt LF (1990) A neuronal cell line (PC12) expresses two beta 1 -class integrins-alpha 1 beta 1 and alpha 3 beta 1 -that recognize different neurite outgrowth-promoting domains in laminin. Neuron 5:651-662.

Towbin H, Staehelin T, Gordon J (1979) Electrophoretic transfer of proteins from polyacrylamide gels to nitrocellulose sheets: procedure and some applications. Proc Natl Acad Sci USA 76:4350-4354.

Trapp BD, Itoyama Y, Sternberger NH, Quarles RH, Webster HD (1981) Immunocytochemical localization of P0 protein in golgi complex membranes and myelin of developing rat Schwann cells. J Cell Biol 90:1-6.

von Heijne G (1984) Analysis of the distribution of charged residues in the $\mathrm{N}$-terminal region of signal sequences: implications for protein export in prokaryotic and eukaryotic cells. EMBO J 3:2315-2318.

Voyvodic JT (1989) Target size regulates caliber and myelination of sympathetic axons. Nature 342:430-433.

Weinberg EL, Spencer PS (1979) Studies on the control of myelinogenesis. III. Signalling of oligodendrocyte myelination by regenerating peripheral axons. Brain Res 162:273-279.

Yen S, Fields KL (1981) Antibodies to neurofilament, glial filament and fibroblast intermediate filament proteins bind to different cell types of the nervous system. J Cell Biol 88:115-126. 